\title{
Faktor Penglibatan Belia Muslim Malaysia dengan Terorisme: Analisis Perspektif PDRM dan Panel Pemulihan Deradikalisasi
}

\section{Factors of Malaysian Muslim Youth Involvement in Terrorism: An Analysis on the Perspectives of PDRM and Deradicalization Panel}

\author{
Mohd Khairul Naim Che Nordin \\ Department of 'Aqidah and Islamic Thought, Academy of Islamic Studies, \\ University of Malaya, 50603 Kuala Lumpur, Malaysia. khairulnaim@um.edu.my \\ Muhamad Syafriz Mhd Nazer \\ Department of 'Aqidah and Islamic Thought, Academy of Islamic Studies, \\ University of Malaya, 50603 Kuala Lumpur, Malaysia. syafriznazer@gmail.com
}

DOI: https://doi.org/10.22452/usuluddin.vol48no1.1

\begin{abstract}
This article examines the involvement factors of Malaysian Muslim youth with terrorism. Various theories have been put forward by researchers to identify these factors in general but studies conducted show that these factors differ from one country to another. Thus, to obtain direct data on the factors of youth terrorist involvement in Malaysia, this study conducted a semi-structured interview with two parties which directly involved in the activities of prevention, control and enforcement of terrorism namely the Anti-Terrorism Unit (E8) Special Branch, Royal Malaysia Police and members of terrorist deradicalization programme, Ministry of Home Affairs. E8 Unit plays a role in identifying and arresting terrorist suspects while members of the deradicalization programme interact directly with the offenders and then carry out the deradicalization process towards them. In addition to this data, the study also conducted interviews with academicians and one family member's of the offender arrested under the Prevention of Terrorism Act (POTA). The results of the interviews were then formulated analytically based on documented library references. The study found that there are five major factors that attract youth into terrorism, namely psychological and personality, religious knowledge, social media, ideology and conflict in Muslim countries. Each of these factors serves as a catalyst for the youth to engage in terrorism. In summary, the identification of these factors is crucial in the efforts of all parties to prevent terrorism among the Malaysian youth.
\end{abstract}

Keywords: Muslim youth, Malaysia, terrorism, Malaysia Royal Police, deradicalization 


\begin{abstract}
Abstrak
Makalah ini mengkaji faktor keterlibatan belia Muslim Malaysia dengan kegiatan terorisme. Pelbagai teori telah dikemukakan oleh para penyelidik bagi mengenalpasti faktor ini secara umum namun kajian yang dijalankan menunjukkan faktor tersebut berbeza dari satu negara dengan negara yang lain. Justeru, bagi mendapatkan data langsung berkenaan faktor penglibatan tersebut di Malaysia, kajian ini telah menjalankan temubual mendalam secara semi-struktur dengan pihak yang terlibat langsung dengan aktiviti pencegahan, pengawalan dan penguatkuasaan terorisme iaitu Bahagian Anti Pengganas (E8) Cawangan Khas, Polis Diraja Malaysia dan ahli panel pemulihan tahanan teroris. Unit E8 berperanan mengenalpasti dan menangkap suspek dan pesalah pengganas manakala ahli panel pemulihan berperanan berinteraksi seterusnya menjalankan proses deradikalisasi terhadap mereka. Selain itu sebagai data sokongan, kajian ini turut menjalankan temubual dengan ahli akademik dan seorang keluarga pesalah yang ditahan di bawah Prevention of Terrorism Act (POTA) atas kesalahan terorisme. Hasil temubual tersebut seterusnya dirumuskan secara analitikal berpandukan rujukan perpustakaan yang didokumentasikan. Kajian mendapati terdapat lima faktor utama yang menarik belia menyertai terorisme iaitu faktor psikologi dan personaliti, faktor pengetahuan dan kefahaman agama, faktor perkembangan media sosial, faktor ideologi dan faktor konflik di negara umat Islam. Setiap faktor tersebut berperanan menjadi faktor penolak dan penarik kepada belia untuk menyertai kegiatan terorisme. Rumusannya, pengenalpastian terhadap faktor-faktor ini amat penting dalam usaha semua pihak untuk mencegah pemikiran terorisme dari terus berkembang di Malaysia khususnya dalam kalangan belia.
\end{abstract}

Kata kunci: belia Muslim, Malaysia, terorisme, PDRM, deradikalisasi

\title{
Pendahuluan
}

Terorisme merupakan suatu faham yang menjadikan pendekatan kekerasan, intimidasi dan keganasan sebagai satu kaedah untuk mencapai tujuan. Ia demi menyebabkan rasa panik, takut dan gerun pihak kerajaan dan masyarakat terhadap organisasi atau kumpulan mereka seterusnya bermatlamat untuk pihak berkepentingan yang disasarkan tadi akur dan patuh terhadap kehendak mereka. Justeru, pendekatan yang digunakan seperti pengeboman, pembunuhan secara rambang atau bersasar dan lainlain secara umumnya digunakan oleh kelompok teroris sama ada di tahap nasional atau antarabangsa. Kajian oleh Global Terorisme Data (GTD) menunjukkan telah berlaku lebih daripada 170,000 
serangan domestik dan antarabangsa semenjak tahun 1970 sehingga 2016. ${ }^{1}$ Sementara purata secara kasar menunjukkan sebanyak $1 \%$ daripada jumlah serangan mengakibatkan 25 atau lebih kecederaan, manakala selebihnya mengakibatkan serangan yang meragut lebih 120,000 nyawa manusia. ${ }^{2}$

Berdasarkan data di atas serta kajian tinjauan sejarah menunjukkan terdapat pelbagai kumpulan dan organisasi dengan latar belakang, ideologi dan lokasi berbeza yang melihat kerelevenan terorisme sebagai satu faham dan pendekatan sehingga ia terus berkembang pada skala global sehingga ke hari ini.

Melihat kepada perkembangan moden, gelombang terorisme boleh dikatakan bermula di era Reign of Terror oleh kumpulan Jacobin pasca Revolusi Perancis, kemudian dikembangkan lagi oleh kumpulan anarkis di Eropah abad ke-19, disusuli gerakan nasionalis sebagai satu bentuk perjuangan anti kolonialisme di era penjajahan dan seterusnya oleh kelompok sayap kiri baru (New Left) di tahun-tahun 1960-1980an. Menurut Rapoport, gelombang terorisme semasa ialah berteraskan agama dengan kemunculan beberapa kumpulan teroris yang berjuang atas nama agama. ${ }^{3}$ Gelombang ini akan terus wujud dengan kemunculan kumpulan lain yang berjuang atas dasar yang berbeza pula. Ia boleh dilihat seperti kelahiran dan perkembangan kelompok radikal berhaluan kanan dalam kalangan White Nationalist dasawarsa ini. Walaupun serangan yang dilakukan oleh kumpulan ini tertumpu secara lokal di tempat ia berkembang namun ideologinya turut berkembang di tahap global.

Faktor kelangsungan setiap gelombang adalah ideologi yang menjadi pemangkin kewujudan sesuatu kumpulan teroris. Di

1 Department of Homeland Security, Centre of Excellent University of Maryland, "Study of Terrorism and Response to Terrorism," Department of Homeland Security Emeritus Center of Excellence, dicapai 10 Disember 2019, http://www.start.umd.edu/research-projects/global-terrorism-database-gtd.

2 Department of Homeland Security, Centre of Excellent University of Maryland, "Study of Terrorism and Response to Terrorism," Department of Homeland Security Emeritus Center of Excellence, dicapai 10 Disember 2019, http://www.start.umd.edu/research-projects/global-terrorism-database-gtd.

3 David C. Rapoport, "The Four Waves of Modern Terrorism," The UCLA International Institute, dicapai 11 Disember 2019, http://international.ucla.edu /media/files/Rapoport-Four-Waves-of-Modern-Terrorism.pdf, 47. 
samping itu, ideologi sesebuah kumpulan itu pula memerlukan dokongan belia yang berperanan penting menyambung matlamat perjuangan kepimpinan generasi terdahulu. Justeru, usaha perekrutan individu-individu berpotensi dalam kalangan belia menjadi antara aktiviti utama sesuatu kumpulan tersebut. Sehubungan itu, kajian ini bermatlamat mengkaji faktor-faktor keterlibatan belia Malaysia dengan kegiatan terorisme menurut perspektif dan sudut pandang pihak yang terlibat secara langsung dengan kegiatan tersebut iaitu Polis Diraja Malaysia dan ahli panel deradikalisasi tahanan teroris. Data sokongan akan turut dianalisis dari ahli akademik dan keluarga pesalah yang terlibat dengan kegiatan terorisme.

\section{Terorisme dan Pendekatan Pencegahannya di Malaysia}

Dalam konteks Malaysia, negara ini turut tidak terlepas daripada kemasukan anasir terorisme khususnya yang bercorak dorongan keagamaan (religious motivation). Antaranya ialah kemunculan Kumpulan Mujahidin Malaysia (KMM) yang ditubuhkan oleh mereka yang pernah terlibat dalam peperangan antara kumpulan Mujahidin dengan Soviet Union di Afghanistan. Matlamat mereka ialah menggulingkan pemerintah sedia ada dan menubuhkan Daulah Islamiyyah Nusantara merangkumi Malaysia, Indonesia dan Selatan Filipina. ${ }^{4}$ Pasca peristiwa 11 September 2001 yang membawa kepada pencerobohan tentera Amerika Syarikat di Iraq dan Afghanistan memberi pengaruh besar kepada segelintir umat Islam untuk menyertai apa yang dinamakan sebagai 'jihad menentang kuffar'.

Semangat tersebut dipenuhi apabila wujud seruan-seruan 'jihad' oleh beberapa kelompok militan dan radikal Islam ketika meletusnya perang di Syria pada tahun 2011. Kemuncaknya apabila Ibrāhīm 'Awwạ̣ Ibrāhīm al-Badrī atau nama samarannya Abū Bakr al-Baghdādī mengisytiharkan dirinya sebagai Khalifah al-Dawlah al-Islāmiyyah fī al-'Irāq wa al-Shām (Daesh) atau Islamic State of Iraq and the Levant (ISIL/ISIS) pada 29 Jun 2014

4 Kamarulnizam Abdullah, "Kumpulan Mujahidin Malaysia (KMM) and Jemaah Islamiyah (JI): The links," Journal of Policing: Intelligence and Counter Terrorism (2009), 29-46. 
dan menyeru semua umat Islam untuk mempertahankan 'khilāfah.'

Rekod polis menunjukkan sejak 2013 sehingga 2018, seramai 102 rakyat Malaysia telah pergi ke Syria untuk menyertai ISIS dan daripada jumlah itu, sebanyak 37 telah terbunuh. ${ }^{6}$ Impak terorisme turut memberi kesan di negara ini melalui ancaman dalam bentuk fizikal. Sebagai contoh, serangan bom di kelab malam Movida di Puchong, Selangor pada 28 Jun 2016 oleh dua individu yang mengaku menyokong ISIS telah mengakibatkan lapan orang awam cedera ${ }^{7}$

Di samping itu, data dari Polis Diraja Malaysia (PDRM) menunjukkan pola unjuran mereka yang terlibat dengan gerakan terorisme adalah semakin muda iaitu antara umur 20 ke 30 tahun berbanding lebih berusia sebelum ini. Bahkan terdapat cubaan merekrut remaja seawal usia14 tahun melalui media sosial yang dapat dijejaki PDRM. ${ }^{8}$ Berdasarkan rekod PDRM juga sebanyak 404 kes tangkapan atas kesalahan terorisme dilakukan dengan 328 tangkapan tersebut adalah dalam kalangan belia. ${ }^{9}$ Jumlah tangkapan melalui Akta Pencegahan Keganasan 2015 (POTA) bagi tahun 2014-2017 pula ialah berjumlah 28 orang dengan 19 orang daripadanya berumur antara 20-35 tahun manakala selebihnya iaitu 9 orang berumur 36-60 tahun. ${ }^{10}$

5 "Who Was Abu Bakr al-Baghdadi?", laman sesawang BBC News, dicapai 9 Novermber 2019, https://www.bbc.com/news/world-middle-east-50200392

6 Zam Yusa dan Hadi Azmi, "Balu Pejuang Negara Islam Terbunuh di Syria Pulang ke Malaysia," laman sesawang Berita Benar, dicapai 10 Disember 2019, https://www.benarnews.org/malay/berita/my-wanita-syria-18102510252018185716.html.

7 "Bom Movida: Dua lelaki Dipenjara 25 Tahun," laman sesawang Astro Awani, dicapai 10 Disember 2019, http://www.astroawani.com/beritamalaysia/bom-movida-dua-lelaki-dipenjara-25-tahun-137227.

8 "Islamic State Recruiter Targeted Local Schoolboy Police Say," laman sesawang Malaymail, dicapai 5 Disember 2019, https://www.malaymail.com /news/malaysia/2014/10/14/islamic-state-recruiter-targeted-local-schoolboypolice-say/763167; "K'jaan Sedia Kertas Putih Kegiatan Keganasan Libatkan Rakyat M'sia," laman sesawang Astro Awani, dicapai 6 Disember 2019, http://www.astroawani.com/berita-malaysia/kjaansedia-kertas-putih-kegiatankeganasan-libatkan-rakyat-msia-47177

9 Pegawai 1 (Unit E8, Bahagian Counter Terroris), dalam temu bual bersama penulis, 12 Julai 2018.

10 "Statistik Tangkapan Elemen Daesh di Bawah POTA," laman sesawang Portal Data Terbuka Malaysia, dicapai 19 Disember 2019, http://www.data 
Beberapa data yang dikemukakan di atas menunjukkan keseriusan masalah terorisme di negara ini khususnya dalam kalangan belia. Langkah menghentikan terorisme tidak memadai melalui pengenalpastian aktiviti terorisme semata tetapi turut perlu didahului dengan pencegahan. Menyedari hakikat terbabit, maka kerajaan telah memperkenalkan beberapa rang undang-undang yang berperanan menyekat pengaruh terorisme daripada terus berkembang.

Antaranya ialah Akta Pencegahan Keganasan 2015 atau Prevention of Terrorism Act 2015 (POTA) yang memperuntukkan pencegahan pelakuan atau sokongan bagi perbuatan keganasan melibatkan organisasi teroris yang tersenarai di negara asing. ${ }^{11} \mathrm{Di}$ samping itu, Akta Kesalahan Keselamatan (Langkah-langkah Khas) 2012 (SOSMA) diperkenalkan sebagai satu langkah pencegahan dengan mengekang aktiviti keganasan daripada berlaku seterusnya mengekalkan ketenteraman awam. Dalam konteks ini, akta tersebut menggariskan terorisme sebagai keganasan terancang terhadap orang atau harta, atau menyebabkan sebilangan besar warganegara takut terhadap keganasan tersebut. Ia turut diluaskan lagi dengan apa-apa sahaja ancaman yang membangkitkan perasaan tidak setia terhadap Yang di-Pertuan Agong, memudaratkan ketenteraman awam di Malaysia serta ancaman berupa tindakan untuk melaksanakan perubahan secara tidak sah tanpa melalui undang-undang. ${ }^{12}$

Justeru, akta yang diperkenalkan ini bersifat mencegah sesuatu tindakan terorisme sebelum ia berlaku. Atas asas tersebut apa jua aspek ancaman yang mengundang pada perlakuan dan tindakan ganas akan diberi perhatian oleh pihak berkuasa. Oleh kerana Yang Di-Pertuan Agong merupakan pemimpin tertinggi Malaysia maka apa-apa sahaja ancaman termasuk yang berkait mencetuskan perasaan tidak setia kepada baginda merupakan satu

.gov.my/data/ms_MY/dataset/statistik-tangkapan-elemen-daesh-dibawah-pota -2014-2017/resource/74a08629-654e-4927-b8a4-6c 734ea1019f.

11 "RUU Pencegahan Keganasan 2015 (POTA) dibentang di Dewan Rakyat," laman sesawang Astro Awani, dicapai 10 Disember 2019, http://www .astroawani.com/berita-malaysia/ruu-pencegahan-keganasan-2015-potadibentang-di-dewan-rakyat-56747.

12 "10 Fakta Anda Perlu Tahu Tentang SOSMA," laman sesawang Astro Awani, dicapai 10 Disember 2019, http://www.astroawani.com/berita-malaysia/10fakta-anda-perlu-tahu-tentang-sosma-76148. 
kesalahan yang tertakluk kepada undang-undang ini. Penjelasan di atas menunjukkan keseriusan kerajaan membendung gejala terorisme daripada wujud dan berkembang di negara ini.

\section{Analisis Kajian Lepas}

Berdasarkan data-data penangkapan yang dinyatakan di atas menunjukkan seakan wujud faktor pendorong yang mencetuskan kemahuan segelintir rakyat Malaysia dalam kalangan belia untuk terlibat dengan terorisme walaupun dasar penguatkuasaan kini lebih diperketatkan. Perkembangan pesat teknologi maklumat serta perubahan hubungan antarabangsa telah menyaksikan lahirnya terorisme bentuk baru yang berbeza dengan pendekatan lama. Tidak seperti generasi terdahulu yang mana kegiatan mereka boleh dikenalpasi melalui sel-sel bawah tanah dan pusat kegiatan rahsia yang ditubuhkan, perkembangan kini menyaksikan kumpulan teroris yang hanya beroperasi melalui internet. Ia menyukarkan pihak berkuasa untuk mengesan mereka serta membataskan kemampuan untuk menyekat golongan yang berpotensi terlibat. Ini kerana, teknologi yang sama digunakan untuk menyebarkan propaganda bagi menarik sokongan seterusnya memberi inspirasi kepada mereka yang berminat.

Oleh kerana itu, kajian oleh Institut Penyelidikan Pembangunan Belia Malaysia (IYRES) pada tahun 2015 menunjukkan internet sebagai faktor pendorong dan saluran media yang memberi pengaruh besar kepada penyebaran doktrin terorisme. Sebanyak $50.4 \%$ saluran media yang digunakan bersumberkan Facebook dan 35\% Youtube. Manakala faktor persekitaran yang mempengaruhi penyebaran ideologi ISIS adalah bersumberkan rakan siber ialah $14.1 \%$ iaitu peratusan terbanyak berbanding faktor-faktor lain. ${ }^{13}$

Berkait faktor pengetahuan pula, kajian oleh IYRES dan Universiti Malaysia Kelantan (UMK) pada tahun 2012 ke atas mahasiswa Universiti Awam (UA) berumur 18 hingga 22 tahun yang beragama Islam menunjukkan masih sedikit belia Malaysia yang mengenali dan memahami tujuan perjuangan kumpulan radikal seperti ISIS. Pada aspek pemahaman, $45.9 \%$ responden

13 Institut Penyelidikan Pembangunan Belia Malaysia, Kajian Pembangunan Kesejahteraan-Pendidikan Agama dan Penglibatan dalam Gerakan Islam Radikal di Kalangan Belia Malaysia (t.tp.: t.p., 2015). 
tidak pasti konsep jihad dalam Islam sama ada ia perintah membunuh secara wewenang atau perintah mempertahankan diri dari serangan berdasarkan justifikasi yang jelas. Begitu juga hampir separuh iaitu $46.4 \%$ responden menjawab tidak pasti berkenaan apakah boleh disebut jihad apabila ada kesanggupan mengorbankan kesucian untuk melayani nafsu ahli kumpulan ISIS. Kajian ini turut menunjukkan media sosial sebagai medium penting yang mampu mempengaruhi dan mendorong belia Malaysia terlibat dengan kumpulan ISIS. ${ }^{14}$

Di samping itu, kajian berkait penerimaan dan penolakan belia kepada ideologi ISIS telah dijalankan oleh IYRES dan Universiti Utara Malaysia (UUM) pada tahun 2015. Dapatan kajian menunjukkan $19.5 \%$ responden dalam kalangan pelajar Institut Pengajian Tinggi menghormati fahaman politik ISIS, $19.5 \%$ sedia menyumbang wang ringgit untuk kumpulan ini, $9.3 \%$ bersetuju dengan menyertai ISIS boleh mendapat balasan syurga dan 4.8\% mengajak rakan-rakan untuk menyokong ISIS. Walaupun secara umumnya dapatan menunjukkan bahawa majoriti pelajar IPT didapati menolak perjuangan ISIS namun, masih terdapat sebilangan kecil pelajar yang masih belum pasti dan ada yang didapati bersetuju, menerima dan menyokong perjuangan tersebut.

Selain itu, kajian berkaitan faktor yang mempengaruhi kecenderungan keterlibatan belia di Malaysia dalam gerakan Islam radikal mendapati bahawa faktor pemahaman agama amat memainkan peranan dalam menentukan penerimaan dan penolakan mereka terhadap gerakan ini. ${ }^{16}$ Bahkan faktor tersebut lebih signifikan berbanding pengaruh kawalan dan media.

Kajian lebih komprehensif telah dilakukan oleh IYRES dalam mengenalpasti profil belia yang terlibat dengan kegiatan terorisme

${ }^{14}$ Nursalihah Ahmad Raston et. al., Persepsi Belia di Malaysia Terhadap Jihad dan Gerakan Islam Radikal (Kuala Lumpur: Unit Penerbitan IYRES, 2016), tiada halaman.

15 Che Mohd Aziz Yaacob et. al., Tahap Kefahaman dan Potensi Penerimaan Pelajar IPTA Terhadap Gerakan ISIS (Kuala Lumpur: Unit Penerbitan IYRES, 2016), tiada halaman.

16 Nursalihah Ahmad Raston et. al., Faktor-faktor yang Mempengaruhi Kecenderungan Keterlibatan Belia di Malaysia dalam Gerakan Islam Radikal (t.tp.: t.p., t.t.), tiada halaman. 
pada tahun 2017. ${ }^{17}$ Pembangunan profil dilihat penting bagi mengenalpasti dorongan dalaman dan luaran yang mempengaruhi belia serta mengkaji ciri perlakuan mereka. Seramai 39 orang responden dalam kalangan belia yang disabitkan kesalahan di bawah SOSMA, POCA dan POTA telah dijadikan sampel kajian melalui edaran soal selidik manakala 11 orang daripada responden tersebut dipilih untuk temubual mendalam. Dapatan kajian menunjukkan terdapat lima faktor yang mendorong belia terlibat dalam kegiatan ekstremisme iaitu faktor psikologi antaranya nilai kendiri rendah dan tahap keagresifan tinggi, faktor luaran iaitu isu dan konflik yang berlaku di negara Islam, faktor ideologi hasil kesalahfahaman dalam agama, faktor individu seperti anti sosial dan naif dan faktor persekitaran seperti media sosial dan ceramah agama yang diikuti.

Kajian berkenaan terorisme di peringkat global telah dijalankan oleh United Nations Office of Counter-Terrorism, Pertubuhan Bangsa-Bangsa Bersatu pada tahun 2017. Satu kajian yang dinamakan "Enhancing the Understanding of the Foreign Terrorist Fighters Phenomenon in Syria" dilakukan bertujuan mengetahui dan memahami fenomena global berkaitan kemunculan pengganas asing yang terlibat dalam konflik ketenteraan di Syria (transnational terrorism). Ia merekodkan faktor-faktor ahli kumpulan pengganas ini keluar dari negara mereka dan terlibat dengan kegiatan terorisme di Syria serta alasan dan justifikasi mereka untuk keluar dari kumpulan tersebut dan kembali ke negara mereka walaupun gagal mencapai tujuan dan matlamat seperti yang diingini. PBB telah berhubung secara langsung dengan 43 individu yang terlibat dari 23 negara berbeza. Hasil kajian menunjukkan subjek terlibat adalah di kalangan belia, lelaki dan tidak menerima pengajian peringkat tinggi. Subjek sebahagian besarnya kurang pendidikan, mempunyai pendapatan yang rendah di negara asal, ada sebahagiannya tidak bekerja dan tidak mempunyai prospek kerjaya. Bahkan mereka juga dikenal pasti hanya memiliki kefahaman peringkat asas berkenaan Islam. ${ }^{18}$

${ }^{17}$ Institut Penyelidikan Pembangunan Belia Malaysia, Kementerian Belia dan Sukan Malaysia, Ringkasan Eksekutif Profil Belia dalam Kegiatan Ekstremisme (Putrajaya: KBS, 2017), tiada halaman.

18 United Nations Office of Counter-Terrorism, "Enhancing the Understanding of the Foreign Terrorist Fighters Phenomenon in Syria", Julai 2017, dicapai 19 
Beberapa kajian yang dinyatakan di atas mengkaji persepsi belia secara umum terhadap pemikiran ekstremisme. Manakala kajian IYRES dan PBB pada 2017 mengkaji secara langsung profil belia yang terlibat dengan terorisme. Namun, sudut pandang penguatkuasa yang terlibat secara langsung dengan jenayah dan kesalahan ini tidak diberi penekanan walhal mereka merupakan pihak yang berada di barisan hadapan dalam mengenalpasti mereka yang terlibat. Ahli panel pemulihan yang mempunyai akses langsung terhadap setiap tahanan teroris turut mempunyai pandangan tersendiri berkait aspek yang dibincangkan ini. Justeru, kajian ini melengkapkan beberapa kajian sedia ada yang secara khusus meneliti faktor-faktor keterlibatan belia dalam kegiatan terorisme.

\section{Metodologi Kajian}

Kajian kes secara deskriptif dipilih untuk kajian ini memandangkan metodenya yang bersifat spesifik dan terfokus iaitu mengkaji faktor-faktor penglibatan belia dengan terorisme. Berdasarkan metode ini, permasalahan dan persoalan sesuatu fenomena melalui sampel yang dipilih dikaji secara mendalam. ${ }^{19}$ Dalam aspek metode pengumpulan data, temu bual secara semistruktur dan bersemuka dijalankan di mana responden dikenalpasti terlebih dahulu dengan soalan-soalan yang dikemukakan direkabentuk berdasarkan rujukan dan pengesahan pakar. Justeru, kajian ini merangkumi aspek pembangunan instrumen, pengumpulan dan analisis data serta analisis hasil dapatan kajian.

\section{Responden Temu Bual}

Seramai enam orang responden ditemubual secara mendalam dengan butiran lanjut mereka adalah seperti berikut:

1. Pegawai 1, Unit E8, Bahagian Counter Terrorism, Cawangan Khas, Polis Diraja Malaysia.

2. Pegawai 2, Unit E8, Bahagian Counter Terrorism, Cawangan Khas, Polis Diraja Malaysia

Disember 2019, https://utveier.no/app/uploads/sites/2/fn-rapport-om-returnerte -fremmedkrigere.pdf

19 Albert J. Mills, ed. Descriptive Case Study, Encyclopedia of Case Study Research (California: Sage Publications, 2010), 15. 
3. Ahmad El-Muhammady bin Muhammad Uthman ElMuhammady, merupakan pensyarah Sains Politik dan pengajian Islam di Universiti Islam Antarabangsa Malaysia (UIAM). Beliau merupakan pakar rujuk Polis Diraja Malaysia berkait kes-kes terorisme serta telah dilantik oleh Kementerian Dalam Negeri sebagai ahli panel deradikalisasi tahanantahanan teroris di Penjara Malaysia.

4. Amran Muhammad, merupakan Pengerusi dan Ketua Eksekutif Islamic and Strategic Studies Institute (ISSI Malaysia) serta telah dilantik oleh Kementerian Dalam Negeri sebagai ahli panel deradikalisasi tahanan-tahanan teroris di Penjara Malaysia.

5. John L. Esposito, merupakan Profesor Agama, Hubungan Antarabangsa dan Pengajian Islam di Georgetown University, Washington D.C, Amerika Syarikat dan Pengarah, Prince Alwaleed Center for Muslim-Christian Understanding di universiti yang sama. Beliau telah menulis pelbagai buku dan artikel berkenaan Islam termasuk berkait terorisme seperti Unholy War: Terror in the Name of Islam, The Islamic Threat: Myth or Reality? dan lain-lain.

6. Aminah (bukan nama sebenar) iaitu isteri kepada tahanan pesalah di bawah akta POTA.

\section{Temu Bual Semi Struktur}

Temu bual secara semi struktur dipilih bagi memberikan kebebasan kepada responden menyampaikan pandangan mereka tanpa terikat dengan peraturan temubual secara khusus. Untuk itu, sebanyak lima soalan telah dikemukakan untuk mencapai objektif kajian yang telah ditetapkan. Perincian soalan adalah seperti berikut:

1. Apakah bentuk-bentuk kegiatan terorisme yang dilakukan belia di Malaysia dan luar negara?

2. Apakah faktor keterlibatan belia dengan kegiatan terorisme?

3. Apakah latar belakang belia yang terlibat dengan kegiatan terorisme?

4. Bagaimanakah bentuk kefahaman belia ini terhadap ajaran Islam?

5. Sejauhmana kecanggihan komunikasi dan capaian informasi memberi pengaruh kepada mereka? 


\section{Dapatan Temu Bual}

1. Bentuk kegiatan terorisme

Soalan ini difokuskan kepada pihak PDRM yang bertanggungjawab mengenalpasti suspek teroris. Menurut Pegawai PDRM 10: "Pihak PDRM menetapkan beberapa kegiatan yang boleh dikategorikan sebagai terorisme iaitu seperti menyokong kumpulan teroris, menyokong perbuatan teroris, menyalurkan dana bantuan kepada kumpulan untuk kegiatan terorisme, memiliki item-item yang boleh dikaitkan dengan kumpulan teroris, mempromosi kegiatan terorisme dan kumpulan teroris, menganggotai kumpulan teroris dan sembunyikan maklumat berkaitan terorisme serta melindungi teroris."

2. Faktor keterlibatan belia dengan kegiatan terrorisme Berkait faktor keterlibatan belia, Pegawai PDRM 1 menyatakan ${ }^{21}$ : "Anak muda mudah dipengaruhi. Mereka terkesan dengan hadith akhir zaman. Peperangan di Syam dan mati syahid, jalan pintas menuju ke syurga adalah pulling factor. Jadi faktornya ialah fahaman jihad yang salah dan jihad qital itu dilihat sebagai yang paling utama."

Merujuk kepada faktor lain pula, Pegawai PDRM 2 menyatakan" : "Pengaruh rakan sebaya. Kemudahan mengakses media sosial. Telegram merupakan ruang yang paling banyak digunakan kerana bilangan ahli dalam kumpulan tele tak terhad dan dari situ mereka sebarkan sebarang maklumat dan menjalankan sesi baiah taat setia."

Bagi perspektif ahli panel deradikalisasi, Ahmad ElMuhammady menyatakan"23: "Keterlibatan belia tak berpunca dari satu faktor bahkan sentiasa ada pelbagai faktor atau multiple factors. Sosial adalah salah satu sebab tapi bukan satu-satunya faktor, faktor ideologi salafi bukan satu-satunya faktor. Jadi ia perlu untuk dilihat secara holistik dengan bermula dari diri sendiri.

${ }^{20}$ Pegawai 1 (Unit E8, Bahagian Counter Terrorism, Cawangan Khas, PDRM), dalam temu bual bersama penulis, 12 Julai 2018.

21 Pegawai 1 (Unit E8, Bahagian Counter Terrorism, Cawangan Khas, PDRM), dalam temu bual bersama penulis, 12 Julai 2018.

22 Pegawai 2 (Unit E8, Bahagian Counter Terrorism, Cawangan Khas, PDRM), dalam temu bual bersama penulis, 12 Julai 2018.

23 Ahmad El-Muhammady bin Muhammad Uthman El-Muhammady (panel pakar deradikalisasi tahanan teroris), dalam temu bual bersama penulis, 13 Ogos 2018. 
Adanya konflik di Asia Barat dan Mindanoa, kalau tiada konflik mungkin peluang keterlibatan rendah.”

Bagi Amran Muhammad pula, beliau berpandangan ${ }^{24}$ : "Antara faktornya seperti pendedahan media sosial, melalui bacaan buku ISIS yang menggalakkan hijrah dan ini juga berkait faham agama. Selain itu ada pengaruh politik kuat seperti adanya kerajaan zalim yang mesti dijatuhkan macam sentimen di Syria, Basyar mesti dijatuhkan. Antara yang utama juga ialah pendedahan naratif Islam menurut Ibnu Taimiyyah dan Muhammad Abdul Wahab yang agresif yang mempengaruhi mereka.

3. Latar belakang belia yang terlibat dengan kegiatan terorisme:

Untuk soalan 3 di atas, Pegawai PDRM 1 menyatakan ${ }^{25}$ : "Sebilangan besar yang berjaya ditangkap kebanyakan mereka mempunyai latar belakang yang bermasalah termasuklah latar belakang keluarga bermasalah, terlibat dengan dadah, gaya hidup bebas, minum arak, clubbing dan sebagainya. Untuk bersihkan diri dari segala dosa maka golongan belia ini direkrut melalui jaminan mati syahid dan menyertai kumpulan ini."

Ahmad El-Muhammady pula menyatakan" ${ }^{26}$ "Kebanyakan yang terlibat dari segi pendidikan adalah mereka yang tidak berpendidikan tinggi melainkan hanya segelintir sahaja. Penjual cendol, penjaga zoo, driver teksi, antara orang awam yang terlibat. Mereka tiada kesedaran pendidikan agama."

Manakala Amran Muhammad menyatakan" ${ }^{27}$ : "Pendidikan mereka pelbagai. Ada kerja technical, engineer, tidak ramai yang berpendidikan agama. Ada juga dalam bidang professional, kerja sendiri dan berniaga."

4. Bentuk kefahaman belia ini terhadap ajaran Islam:

Soalan ini difokuskan terhadap ahli panel deradikalisasi kerana mereka berhubung langsung dengan para tahanan. Berdasarkan

${ }^{24}$ Amran Muhammad (panel pakar deradikalisasi tahanan teroris) dalam temu bual bersama penulis, 7 Ogos 2018.

25 Pegawai 1 (Unit E8, Bahagian Counter Terrorism, Cawangan Khas, PDRM), dalam temu bual bersama penulis, 12 Julai 2018.

26 Ahmad El-Muhammady (panel pakar deradikalisasi tahanan teroris), dalam temu bual bersama penulis, 13 Ogos 2018.

27 Amran Muhammad (panel pakar deradikalisasi tahanan teroris) dalam temu bual bersama penulis, 7 Ogos 2018 . 
soalan keempat, Ahmad El-Muhammady menyatakan"28: "Tak kesemua yang ditahan itu ada fikrah jelas melainkan segelintir yang boleh hurai fikrah mereka secara jelas dan meyakinkan. Mereka bersemangat untuk pertahankan agama namun tiada ilmu. Mereka ada fikrah Daulah Islamiyyah iaitu negara Islam yang amalkan hukum Islam. Jika tiada, tak sah sebagai negara Islam. Jadi, cara realisasikannya adalah jihad. Yang ini, semua tahanan berfikiran sedemikian cuma mereka tak sedar fahaman itu salah. Bila ditanya mereka kata ini jihad."

Manakala Amran Muhammad menyatakan"29: "Mereka ikuti usrah, tahu tentang jihad, hukum Islam, kerajaan taghut dan hukum hudud. Hujah-hujah mereka diulang semula seperti tahun 80an tanpa kefahaman sebenar sebab mereka didoktrin. Kadangkadang sebahagian mereka menyindir antara satu sama lain kerana ada yang menyertai group yang ekstrem. Ada sebahagian yang mungkin sudah masuk 5 ke 6 bulan dengan kumpulan ini dan terus komited dengan ideologi dan tidak faham jihad yang sebenar menurut syarak."

5. Peranan kecanggihan komunikasi dan capaian informasi:

Berkait soalan kelima pula, Pegawai PDRM 1 menyatakan ${ }^{30}$ : "Internet kini mudahkan capaian maklumat. Mudah untuk hasilkan bahan letupan. Antara yang berjaya ditangkap atas kesalahan membuat bahan letupan, hanyalah berpandukan kepada Google dan Youtube sahaja. Komunikasi juga sangat mudah, sebarang perbincangan hanya dalam talian. Mereka tak perlu berkumpul di suatu tempat untuk adakan perbincangan."

Bagi Pegawai PDRM 2, beliau melihat peranan tersebut pada aspek berikut ${ }^{31}$ : "Dengan adanya media sosial manusia akan terusmenerus menggunakannya. Faham ini pula seperti cendawan tumbuh dan ianya tak akan pernah terhenti. Selagi tiada sekatan penggunaan media sosial selagi itu faham ini akan terus berkembang. Walaubagaimanapun untuk menyekat dari

28 Ahmad El-Muhammady (panel pakar deradikalisasi tahanan teroris), dalam temu bual bersama penulis, 13 Ogos 2018.

29 Amran Muhammad (panel pakar deradikalisasi tahanan teroris) dalam temu bual bersama penulis, 7 Ogos 2018 .

30 Pegawai 1 (Unit E8, Bahagian Counter Terrorism, Cawangan Khas, PDRM), dalam temu bual bersama penulis, 12 Julai 2018.

31 Pegawai 2 (Unit E8, Bahagian Counter Terrorism, Cawangan Khas, PDRM), dalam temu bual bersama penulis, 12 Julai 2018. 
menggunakannya adalah mustahil kerana kesemua manusia memerlukannya. Sekalipun SKMM berjaya menyekat sebarang akaun media sosial berkaitan kumpulan ini, maka akan muncul pula akaun yang baru."

Dalam hal ini, Ahmad El-Muhammady menyatakan ${ }^{32}$ : "Kajian Institut Belia, 39 tahanan yang terlibat, hasil kajian mendapati yang Facebook, Telegram adalah $85 \%$ antara punca mereka dapat maklumat. Keseluruhan yang terlibat ini bermula dengan sosial media dan maklumat yang mereka perolehi. Ini berlaku kerana belia adalah pengguna tegar."

Amran Muhammad menyatakan"33: "Mereka ada portal tersendiri sebagai agen penyebar maklumat. Sebab itu mereka menggunakan IT sepenuhnya sebagai alat menyebarkan ideologi seperti Whatsapp dan Facebook. Untuk sebar ideologi maka Dabiq sebagai teks rasmi propaganda mereka diluaskan. Dalam masa yang sama mereka cekap buat video dengan menarik orang awam guna ayat al-Quran, video gambar-gambar disembelih dan dibakar dan sebagainya."

\section{Perbincangan dan Analisis Dapatan Temu bual}

Bahagian ini akan menganalisis dapatan temu bual yang telah direkodkan seperti yang dinyatakan di atas. Berdasarkan pengkategorian oleh pihak berkuasa seperti yang dinyatakan di soalan satu, mereka yang boleh dikaitkan dengan terorisme bermula dengan sokongan yang boleh dilihat daripada kemampuan memiliki item seperti buku atau dokumen yang menjadi rujukan teroris serta komen, status dan perkongsian yang dilihat menyokong terorisme serta bersimpati terhadap teroris di laman sosial.

Pengenalpastian dan pengkategorian ini bersifat pencegahan bagi memastikan individu yang dilihat condong menyokong terorisme boleh dipulihkan lebih awal. Berasaskan klasifikasi ini juga, tiada individu yang boleh terlepas daripada sebarang tindakan perundangan sekiranya mereka melibatkan diri dalam terorisme. Pernguatkuasaan akta seperti yang telah dijelaskan

\footnotetext{
32 Ahmad El-Muhammady (panel pakar deradikalisasi tahanan teroris), dalam temu bual bersama penulis, 13 Ogos 2018.

33 Amran Muhammad (panel pakar deradikalisasi tahanan teroris), dalam temu bual bersama penulis, 7 Ogos 2018 .
} 
sebelum ini berperanan penting memastikan pihak berkuasa mampu mengambil tindakan terhadap mana-mana individu yang berpotensi terlibat aktif sehingga seterusnya mungkin direkrut menjadi teroris.

Atas asas tersebut, Akta Pencegahan Keganasan (Prevention of Terrorism Act) atau POTA memberi kuasa kepada polis menahan suspek teroris tanpa waran selama 60 hari. Ahli Lembaga Pencegahan Keganasan yang dilantik dengan perkenan Yang diPertuan Agong pula mempunyai kuasa menahan individu terbabit sehingga dua tahun. Manakala Seksyen 4 (1) Akta Kesalahan Keselamatan (Langkah-Langkah Khas) 2012 memperuntukkan penangkapan dan penahanan mana-mana individu berkenaan dengannya boleh dilakukan oleh polis tanpa waran sekiranya dipercayai dia terlibat dalam kesalahan keselamatan. Individu tersebut pula boleh ditahan untuk tempoh selama 24 jam bagi penyiasatan dan, tempoh siasatan tersebut boleh dilanjutkan tidak lebih dari 28 hari bagi membantu penyiasatan. ${ }^{34}$ Justeru, POTA berkait pencegahan terorisme secara khusus di samping berperanan memperkasa akta sedia ada iaitu SOSMA yang menjadi akta penting selepas pemansuhan Akta Keselamatan dalam Negeri (Internal Security Act (ISA)).

Kedua-dua akta ini adalah selaras dengan Perkara 149 Perlembagaan Persekutuan yang menetapkan kesalahan terhadap perbuatan subversif, tindakan yang memudaratkan ketenteraman awam dan sebagainya. Sebarang tindakan yang menyebabkan keganasan terancang terhadap orang atau harta, atau untuk menyebabkan sebilangan besar warganegara takut akan keganasan itu adalah tertakluk dalam perkara ini. ${ }^{35}$ Disamping itu, ia juga selaras dengan semangat dan tujuan Resolusi Majlis Keselamatan PBB (UNSCR) 2178 dalam memantau dan mengawal selia Militan Pengganas Asing (FTFs). ${ }^{36}$ Langkah-langkah counter terrorism

${ }^{34}$ Laws of Malaysia, Act 747, Security Offences (Special Measures) Act 2012, 9-10.

35 Perlembagaan Persekutuan (Kuala Lumpur: International Law Book Service, 2018), 163.

${ }^{36}$ United Nation, Resolution 2178 (2014), Threats to International Peace and Security Caused by Terrorist Acts, laman sesawang UNSCR Search Engine for the United Nations, dicapai 19 Disember 2019, http://unscr.com/en/resolutions 12178 
seperti yang dinyatakan dalam resolusi terbabit dimanifestasikan dalam akta sedia ada seperti yang telah dibincangkan di atas.

Berdasarkan temu bual tersebut juga, boleh dirumuskan terdapat sebanyak lima faktor utama yang menarik belia menyertai terorisme iaitu faktor psikologi dan personaliti, faktor pengetahuan dan kefahaman agama, faktor perkembangan media sosial, faktor ideologi dan faktor konflik di negara umat Islam. Ia boleh dirumuskan seperti rajah 1 di bawah:

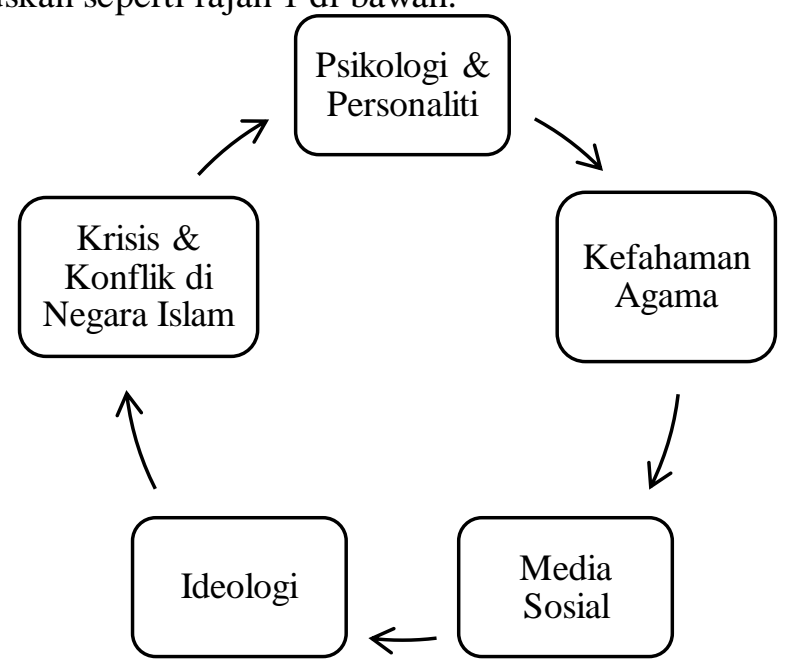

Rajah 1: Faktor Penglibatan Belia dengan Terorisme Faktor-faktor ini dianalisis dan dirumuskan seperti huraian berikut:

a. Psikologi dan Personaliti

Berdasarkan temu bual, analisis kajian lepas serta dapatan kajian perpustakaan, faktor utama yang mendorong belia terlibat dengan kegiatan terorisme ialah diri individu yang memiliki sikap dan personaliti yang hampir sepunya iaitu nilai kendiri rendah dan tahap psikologi yang tidak stabil.

Ini kerana, sebilangan besar tahanan yang ditangkap dikenalpasti mempunyai latar belakang kehidupan bermasalah seperti keluarga yang berkonflik, terlibat dengan penagihan dadah, gaya hidup bebas, memiliki pengalaman masa lalu yang negatif dan sebagainya. ${ }^{37}$ Impaknya melahirkan beberapa ciri yang sama

${ }^{37}$ Pegawai 1 \& 2 (Unit E8, Bahagian Counter Terrorism, Cawangan Khas, PDRM) dalam temu bual bersama penulis, 12 Julai 2018; Aminah (isteri 
iaitu kurang keyakinan diri serta perasaan nilai diri rendah sehingga tidak meletakkan penghargaan diri yang tinggi kepada nyawa dan keselamatan sendiri. Ia turut melahirkan sikap diri yang narsistik iaitu kecenderungan tinggi untuk menjadi 'hero' bagi menampung rasa rendah diri tersebut. ${ }^{38}$ Mereka yang dibesarkan dari keluarga bermasalah dan tidak mempunyai hubungan yang rapat dengan ibubapa turut cenderung bersikap anti-sosial dan mempunyai kesukaran bergaul dengan rakan sebaya. Impaknya ialah mereka mencari 'circle' di luar norma, berciri subversif dan mampu menaikkan imej diri. Perasaan rendah diri yang terbit dari rasa bersalah dan kemahuan bertaubat turut mendorong sebilangannya menyertai aktiviti yang dianggap 'jihad' sebagai satu bentuk penebusan kesalahan masa lalu.

Tambahan pula, keadaan jiwa remaja dalam rentang masa tersebut menunjukkan keadaan psikologi mereka yang bergelora dalam memilih dan menentukan identiti diri, mudah dipengaruhi persekitaran di samping idealis, bersemangat dan bercita-cita tinggi. ${ }^{39}$

b. Kefahaman Agama

Salah pentafsiran agama turut menyumbang kepada faktor dorongan ini. Sebahagian tahanan tidak mempunyai fikrah yang jelas berkenaan perjuangan mereka sendiri. Ia dibuktikan apabila mereka gagal memberi penjelasan yang meyakinkan tentang ideologi yang dipegang. ${ }^{40}$ Ironinya mereka sangat mementingkan doktrin penubuhan Daulah Islamiyyah atau negara Islam yang diperintah orang Islam dan wajib berhukumkan hukum Allah. Jika syarat ini tiada maka sesebuah negara tidak layak disebut negara Islam sehingga bagi sesetengah yang lebih radikal melihat satu keperluan untuk diperangi pemerintah yang tidak menegakkan hukum Allah walaupun mereka dalam kalangan Muslim. Maka

kepada tahanan pesalah di bawah SOSMA), dalam temu bual bersama penulis, 19 Ogos 2018.

38 Ahmad El-Muhammady (panel pakar deradikalisasi tahanan teroris), dalam temu bual bersama penulis, 13 Ogos 2018.

39 Robert J. Hedaya, The Teenager's Brain: Do you understand your teenager's thoughts?, laman sesawang Psychology Today, dicapai 9 Januari 2020, https://www.psychologytoday.com/us/blog/health-matters/201006/theteenagers-brain.

40 Amran Muhammad (panel pakar deradikalisasi tahanan teroris), dalam temu bual bersama penulis, 7 Ogos 2018. 
untuk merealisasikan penubuhan negara tersebut, jihad perlu dilaksanakan. $^{41}$

Oleh itu, doktrin hakìmiyyah yang diangkat sebagai usul iman difahami berbeza dengan kefahaman jumhur ulama. Ini kerana aspek keyakinan berkenaan peletak hukum iaitu Allah SWT adalah suatu dimensi yang membabitkan akidah manakala aspek perlaksanaannya tertakluk kepada dimensi fiqh yang tertakluk pula kepada hukum dan syarat tertentu. Dalam persoalan inilah muncul kelompok radikal yang membangunkan paradigma takfiri melalui pemahaman yang salah terhadap permasalahan di atas. Kelompok ini melihat masyarakat yang kurang sempurna dalam menerapkan hukum-hukum fiqh dianggap telah mengambil hak prerogatif Allah dalam menentukan hukum dan hal itu didakwa sebagai penentangan terhadap-Nya sehingga akhirnya masyarakat ini dikafirkan. ${ }^{42}$

Kefahaman berkenaan aspek ini memerlukan pengetahuan yang mendalam dan pembelajaran yang intensif kerana ia mencakupi aspek akidah dan wacana fiqh. Namun, kajian-kajian yang dijalankan menunjukkan pendidikan agama yang dilalui oleh mereka yang terlibat sebahagian besarnya hanya di tahap sekolah menengah dengan latar belakang kerjaya yang berbeza. ${ }^{43}$ Naratif Islam yang dipegang pula dipengaruhi oleh karya-karya 'jihad' beberapa tokoh kumpulan radikal Islam.

\section{c. Media Sosial}

Seperti yang telah dinyatakan dalam temu bual dan beberapa kajian di atas, media sosial menjadi medium untuk kumpulan teroris menyebarkan propaganda dan mesej 'perjuangan' mereka. Ia dalam masa yang sama menjadi faktor penarik kepada belia yang mempunyai akses mudah terhadap internet untuk akhirnya terlibat dengan gerakan ini. Media sosial seperti Facebook, Telegram Wechat, WhatsApp dan sebagainya dijadikan sumber maklumat untuk mengikuti perkembangan, berkongsi informasi

41 John L. Esposito (Profesor Agama, Hubungan Antarabangsa dan Pengajian Islam, Georgetown University, Washington D.C; Ahmad El-Muhammady (panel pakar deradikalisasi tahanan teroris), dalam temu bual bersama penulis, 13 Ogos 2018.

${ }^{42}$ Usāmah Sayyīd al-Azharī, al-Haqq al-Mubīn fĭ al-Rad 'alā man Tala'aba bi al-Dìn: al-Tayyārāt al-Mutațarrifah min al-Ikhwān ilā al-Dā'ish fì Mīzān al'Ilm (Abū Dhabi: Dār al-Faqīh, 2016), 21.

43 IYRES, Ringkasan Eksekutif, 25 
dan berkomunikasi. Kerana itu, terdapat beberapa kumpulan yang dikesan mempunyai portal laman sesawang tersendiri. ${ }^{44}$ Bahkan berdasarkan rekod PDRM, Telegram merupakan ruang komunikasi yang paling banyak digunakan kerana bilangan keahliannya yang tidak terhad. Disamping berperanan untuk menyebarkan maklumat, ia turut digunakan sebagai medium menjalankan sesi baiah taat setia terhadap kumpulan dan pimpinan yang diikuti. ${ }^{45}$ Justeru, sebarang perbincangan yang berlaku hanya dalam talian dan pada bila-bila masa tanpa mereka perlu berkumpul di sesuatu tempat untuk mengadakan perbincangan. Selain itu, akses mudah dan pantas di beberapa capaian seperti Google dan Youtube turut digunakan untuk mempelajari kaedah membuat bahan letupan, menggunakan senjata api dan lain-lain. ${ }^{46}$

Bagi aspek media sebagai bahan propaganda, kumpulan teroris menggunakan pendekatan kecanggihan video bermatlamatkan dua objektif. Yang pertama sebagai medium menarik minat mereka yang berpotensi untuk direkrut dan yang kedua bagi menyebarkan rasa gerun terhadap pihak berkuasa dan masyarakat yang menentang mereka. Untuk objektif yang pertama, video-video serangan terhadap markaz operasi musuh, kejayaan menawan beberapa kota di samping temu bual dengan anggota kumpulan sambil disulami alunan bacaan al-Quran yang secara khusus berkait ayat jihad digunakan. Manakala untuk objektif kedua, mesej dalam bentuk amaran dari pimpinan tertinggi, gambar dan video musuh diseksa dan dibunuh serta video pengeboman di sesuatu tempat dipertontonkan bagi mendatangkan rasa takut terhadap mereka. Hal ini boleh diteliti dalam pelbagai video yang ditularkan sendiri oleh ISIS.

d. Ideologi

Setiap kumpulan apatah yang bermotifkan politik turut mempunyai ideologi perjuangannya. Kumpulan radikal Islam secara umumnya berpegang kepada konsep Tauhid Tiga yang

${ }^{44}$ Amran Muhammad (panel pakar deradikalisasi tahanan teroris) dalam temu bual bersama penulis, 7 Ogos 2018; Aminah (isteri kepada tahanan pesalah di bawah SOSMA), dalam temu bual bersama penulis, 19 Ogos 2018.

45 Pegawai 1 (Unit E8, Bahagian Counter Terrorism, Cawangan Khas, PDRM), dalam temu bual bersama penulis, 12 Julai 2018.

${ }^{46}$ Pegawai 1 (Unit E8, Bahagian Counter Terrorism, Cawangan Khas, PDRM), dalam temu bual bersama penulis, 12 Julai 2018. 
diolah secara radikal. ${ }^{47}$ Konsep Tauhid Rububiyyah yang berkait pegangan bahawa Tuhan menjadikan alam dan seluruh makhluk diradikalkan sehingga mengimplikasikan kewajipan kepada setiap manusia untuk melaksanakan amalan dan hukum Islam dan kegagalan melaksanakannya dihukum kafir dan layak dibunuh. Ia berkait dengan konsep al-Hakmiyyah atau al-Mulkiyyah iaitu Allah satu-satunya pembuat dan peletak hukum dan dengan itu mereka menolak perlembagaan negara yang dianggap sebagai hukum taghut serta menetapkan kewajipan untuk ditubuhkan Dawlah Islāmiyyah.

Tawhìd Ulūhiyyah berkait kedudukan Allah sebagai Tuhan yang layak disembah beserta penolakan taghut, kufur, nifaq dan perbezaan orang Islam-Kafir serta negara Islam-negara kafir telah mengimplikasikan penolakan kepada sistem demokrasi buatan manusia, pengkafiran terhadap pendokongnya serta pengisytiharan perang terhadap penguasa dan negara Islam yang dilihat 'bersubahat' dengan negara kafir. Manakala Tawhìd al-Asmā' wa al-Sifāt yang berkait keyakinan Allah memiliki nama dan sifat yang indah mengimplikasikan kepada gejala pemusnahan simbol penyembahan serta peninggalan sejarah agama lampau. ${ }^{48}$

Justeru, Islam dilihat tidak hanya boleh dikembangkan melalui dakwah semata tetapi juga perlu melalui perlaksanaan jihad. Pengisytiharan jihad pula cukup memadai dengan 'fatwa' yang dikeluarkan oleh pemimpin kumpulan tertentu apabila berlaku krisis di negara umat Islam. Dalam konteks inilah ideologis seperti Abdullah 'Azzam meletakkan jihad sebagai yang terpenting selepas akidah. ${ }^{49}$ Wacana jihad pula diradikalkan pada aspek diharuskan bahkan untuk keadaan tertentu diwajibkan tindakan keganasan seperti pengeboman bunuh diri sama ada di markaz musuh, kawasan awam atau kepada umat Islam yang dilabel pengkhianat. Bagi membezakan tindakan bunuh diri yang menyebabkan dosa besar dalam Islam, Abū Hamzah al-Mazrī sebagai contoh menyatakan bahawa perlakuan bunuh diri adalah

47 Pegawai 2 (Unit E8, Bahagian Counter Terrorism, Cawangan Khas, PDRM) dalam temu bual bersama penulis, 12 Julai 2018.

48 Ahmad El-Muhammady (panel pakar deradikalisasi tahanan teroris) dalam temu bual bersama penulis, 13 Ogos 2018.

49 'Abd Allāh 'Azzām, Defense of the Muslim Lands: The First Obligation After Iman, dicapai 5 Disember 2019, https://archive.org/details/Defense_of_the _Muslim_Lands 
tindakan peribadi akibat tekanan yang dialami manakala operasi bunuh diri oleh kumpulan ini adalah untuk Allah dan agamaNya. ${ }^{50}$

Pegangan dan keyakinan ini dikuatkan lagi dengan fenomena semasa yang berlaku dan dikaitkan dengan isyarat akhir zaman serta hadis-hadis nabi SAW berkenaan dengannya. Sebagai contoh, peristiwa yang berlaku di Iraq dan Syria dikaitkan dengan peristiwa perang besar yang dinyatakan akan berlaku sebelum menjelangnya hari kiamat. Ia dijadikan sebagai satu propaganda penting untuk menarik belia supaya tidak terlepas dari menyertai 'perang akhir' antara muslim dan kafir ini, selanjutnya menggapai syahid dan peluang ke syurga. ${ }^{51}$

e. Krisis dan Konflik di Negara Islam

Gelombang radikalisme secara umumnya lahir daripada krisis yang berlaku di sesuatu tempat. ${ }^{52}$ Dalam konteks dunia Islam secara khusus, awal abad ke-20 menyaksikan kebangkitan gerakan Islamisme berpaksikan politik melalui jalan damai dan tanpa keganasan. Namun tahun-tahun 1970-1990-an menunjukkan kemunculan gerakan bersenjata apabila berlaku pencerobohan USSR terhadap Afghanistan serta pendudukan Israel secara berterusan di wilayah Palestin. Karya-karya tulisan 'Abd Allah 'Azzam dijadikan sebagai rujukan penting oleh kelompok radikal Islam sehingga masa kini.

Tulisan Defense of the Muslim Lands: The First Obligation After Iman menghuraikan kewajipan Muslim mempertahankan Afghanistan dan Palestin serta beberapa fatwa berkenaan jihad pada waktu tersebut manakala karya kedua beliau iaitu Join the Caravan menjadi mesej seruan dan motivasi kepada umat Islam

50 Assaf Moghadam, "Motives for Martyrdom: Al-Qaida, Salafi Jihad, and the Spread of Suicide Attacks", International Security 33, no. 3 (Winter, 2008/2009), 63.

51 Pegawai 1 (Unit E8, Bahagian Counter Terrorism, Cawangan Khas, PDRM), dalam temu bual bersama penulis, 12 Julai 2018; Aminah, (isteri kepada tahanan pesalah di bawah SOSMA), dalam temu bual bersama penulis, 19 Ogos 2018.

52 John L. Esposito (Profesor Agama, Hubungan Antarabangsa dan Pengajian Islam, Georgetown University, Washington D.C.), dalam temu bual bersama penulis, 19 April 2018. 
untuk menyertai jihad di Afghanistan yang dihukumkan sebagai fard 'ayn kepada semua. ${ }^{53}$

Gelombang kedua berlangsung pasca pengunduran tentera Soviet dari bumi Afghanistan di mana berlaku krisis yang berbeza iaitu tumpasnya gerakan bersenjata di Mesir dan Algeria, campur tangan Amerika Syarikat di Asia Barat dan ancaman berterusan Israel di Palestin. Pemfokusan perjuangan dengan itu beralih kepada 'musuh jauh' iaitu Amerika Syarikat. Latar belakang kepada krisis ini lebih jelas boleh dilihat bersumberkan deklarasi jihad terhadap Israel dan tentera Salib (kuasa Barat) (Declaration of the World Islamic Front for Jihad Against the Jews and the Crusaders) yang ditandatangani oleh 'Usāmah bin Muhammad bin Ladin (Arab Saudi), Ayman al-Ẓawāhīrī (Mesir), Abū Yāsir Rifā'ī Aḥmad Ṭaḥ̄a (Mesir), Mir Hamzah (Pakistan) dan Fazlur Rahman (Bangladesh).

Deklarasi 1998 yang dinyatakan sebagai 'fatwa' tersebut menyeru semua umat Islam khususnya belia untuk membunuh rakyat Amerika dan sekutunya sama ada dalam kalangan tentera mahupun orang awam di mana sahaja dengan matlamat supaya kuasa asing diketuai Amerika keluar dari negara Islam serta tidak lagi memberi ancaman terhadap umat Islam. Seruan tersebut termasuk 'fatwa' mengharuskan rompakan kepada pihak yang dinyatakan serta menggulingkan pemerintah yang didakwa bersekongkol dengan kuasa Barat. $^{54}$ Dua tahun sebelum itu, 'Usāmah telah mengeluarkan deklarasi perang (Declaration of Jihad Against the Americans Occupying the Land of the Two Holy Mosques) yang menjelaskan pegangan dan prinsip perjuangan beliau. Seperti Abdullah 'Azzam, beliau melihat jihad sebagai kewajipan terpenting selepas syahadah, bahkan dengan pendirian

53 Abdullah "Azzam, "Defense of the Muslim Lands: The First Obligation After Iman," laman sesawang Internet Archieve, dicapai 5 Disember 2019, https://archive.org/details/Defense_of_the_Muslim_Lands; Abdullah 'Azzam, "Join the Caravan," diakses 5 Disember 2019, https://ebooks.worldofislam .info/ebooks/Jihad/Join\%20the\%20Caravan.pdf

54 "Declaration of the World Islamic Front for Jihad Against the Jews and the Crusaders," website World Islamic Front Statement, 23 Februari 1998, dicapai 25 Disember 2019, https://fas.org/irp/world/para/docs/980223-fatwa.htm 
yang lebih radikal iaitu membolehkan pembunuhan orang awam serta pemusnahan infrastruktur awam sekiranya perlu. ${ }^{55}$

Dokumen-dokumen yang dinyatakan ini menunjukkan kewujudan ideologi yang lahir akibat krisis yang berlaku di pelbagai negara umat Islam. Walaupun ia tidak boleh dikaitkan secara langsung dengan belia di Malaysia, namun idea-idea yang mereka pegang berkenaan jihad dan negara Islam adalah selari dan sejajar dengan dokumen tersebut.

Krisis yang mencetuskan gelombang ketiga boleh dikatakan bermula pada 19 Mac 2003 apabila Amerika Syarikat melakukan pencerobohan ketenteraan di Iraq. Ketidaktentuan dan konflik terus berlanjutan apabila berlakunya kebangkitan revolusi musim bunga atau Arab Spring yang bermula di Tunisia pada tahun 2010 dan seterusnya merebak ke beberapa negara lain termasuk Syria. Kumpulan radikal Islam telah mengambil kesempatan atas ketidakstabilan yang berlaku dengan menawan beberapa lokasi, mengisytiharkan penubuhan negara Islam dan mengimplementasikan apa yang disebut sebagai hukum syariat. Ia merupakan gelombang yang memberi impak paling besar dan popular kerana ISIS ketika zaman kemuncaknya direkodkan berjaya mengumpul hampir 30,000 pejuang dari negara asing, aset bernilai $\$ 2$ bilion serta menguasai wilayah luas antara Iraq dan Syria. ${ }^{56}$

Ideologis utama mereka ialah Abū Muș ab al-Zarqāwī yang merupakan Amīr Tanżìm Qā'idah al-Jihād fì Bilād al-Rāfidayn iaitu cabang organisasi al-Qā'idah di Iraq dan Abū Bakr alBaghdādī yang mengisytiharkan dirinya selaku khalifah seperti yang telah dijelaskan sebelum ini. Karya tulisan strategis alQā'idah, Abū Bakr Nājī iaitu The Management of Savagery berkenaan kaedah penawanan sesebuah negara dijadikan teks utama perjuangan. ${ }^{57}$ Tidak seperti aktiviti serangan yang dilakukan secara rawak oleh 'Usāmah, bentuk perjuangan ISIS bersifat tradisional dengan mempunyai wilayah tersendiri. Al-Zarqāwī

55 Usamah bin Ladin, Declaration of Jihad Against the Americans Occupying the Land of the Two Holy Mosques (London: al-Quds al-'Arabī, 1996), 1-5.

56 Patrick Cockburn, The Rise of Islamic State: ISIS and the New Sunni Revolution (London: Verso, 2015), 3.

57 Abū Bakr Nājīi, The Management of Savagery, terj. William McCants, dicapai 10 Nov 2019, http://media.leeds.ac.uk/papers/vp0167b8.html. 
melalui video-video propagandanya pula menunjukkan perjuangan bersenjatanya sebagai 'cool' dan untuk anak muda.

Oleh itu, konflik Asia Barat seperti di Syria dan Iraq serta Nusantara seperti di Mindanao, Selatan Filipina telah menarik belia Malaysia untuk membantu nasib saudara seagama. Tambahan pula konflik yang berlaku tersebut disebabkan campur tangan kuasa asing dari Barat yang dilihat sebagai tindakan penindasan dan penaklukan secara berterusan terhadap Islam dan umat Islam. Faktor atau motivasi utama penglibatan mereka bermula dengan rasa simpati terhadap penganut seagama yang ditindas. Gambaran kelompok Sunni di Syria yang digambarkan seperti ditekan dan diserang oleh kerajaan Assad yang berfahaman Syiah turut menjadi pendorong utama penglibatan mereka. Perasaan ini kemudian berkembang sehingga mereka merasakan suatu kewajipan agama untuk membela kelompok sealiran yang tertindas dan dalam masa yang sama menjatuhkan kerajaan kafir dan zalim tersebut. ${ }^{58}$ Pihak ISIS sebagai contoh menggunakan terma 'hijrah' untuk menarik belia menganggotai kumpulan mereka, iaitu penghijrahan dari keselesaan hidup di negara asal dan menuju ke negara Islam yang memerlukan pengorbanan jiwa dan 'jihad bersenjata.'

\section{Analisis Faktor}

Kelima-lima faktor yang dihuraikan di atas adalah saling berkait dan melengkapi sehingga melahirkan dorongan belia untuk terlibat dengan terorisme. Lima faktor ini juga boleh dikategorikan kepada faktor penarik dan penolak atau faktor dalaman dan luaran. Faktor penolak ialah keadaan diri individu itu sendiri serta kefahaman agama yang dimiliki. Manakala faktor penarik ialah ideologi serta konflik dan penaklukan yang dilakukan oleh kuasa Barat ke atas negara umat Islam. Medium yang menjadi faktor penarik tersebut pula ialah media sosial. Oleh itu, keterlibatan belia tidak berpunca hanya daripada satu faktor khusus tetapi pelbagai faktor yang saling berkait dan mempengaruhi.

${ }^{58}$ United Nations Office of Counter-Terrorism, "Enhancing the Understanding of the Foreign Terrorist Fighters Phenomenon in Syria", 2017. 


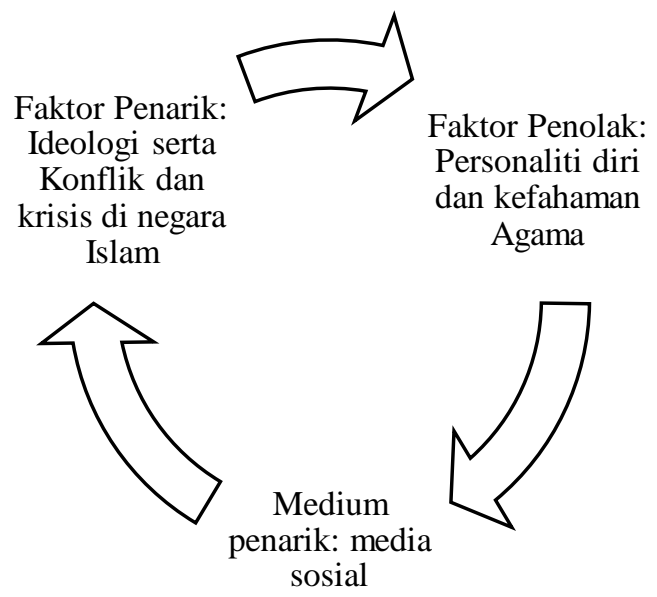

Rajah 2: Faktor Penolak dan Penarik

Berdasarkan faktor-faktor ini juga, ia membentuk pola pemikiran belia untuk akhirnya terlibat dengan kegiatan radikal. Ia bermula dengan pendedahan yang diperolehi di media sosial berkenaan konflik dan peperangan yang terjadi di beberapa negara Islam, disulami oleh perasaan untuk membantu disamping keinginan narsistik akibat rasa rendah diri sehingga melahirkan keinginan menyertai kumpulan tertentu. Dengan pengetahuan agama yang cetek, mereka dimanipulasi dengan doktrin dan ideologi sesuatu kumpulan sehingga baiah sebagai satu komitmen taat setia dilakukan dan akhirnya ia membawa kepada tindakan.

Walapun peratusan mereka yang terlibat adalah kecil namun ia tidak boleh diambil ringan kerana ideologi yang disebarkan berlaku secara senyap dan rahsia. Dalam konteks Malaysia sebagai negara majmuk, doktrin yang tidak menerima kepelbagaian pandangan boleh membawa kepada ketegangan antara kaum dan akhirnya konflik berdarah. Ia turut memberi imej negatif kepada kesucian agama Islam yang jika bersandarkan naratif ini menggalakkan perseteruan, peperangan dan keganasan.

Tewasnya ISIS di kubu terakhir mereka di Baghuz sempadan Syria dan Iraq telah melahirkan satu gelombang krisis yang baru. Abū Bakr al-Baghdādi dalam video pertama beliau pada April 2019 selepas lima tahun 'menghilang' dan kemudiannya selepas itu diisytiharkan terbunuh oleh Amerika Syarikat telah menyeru 
para pejuang dan penyokongnya melakukan serangan secara 'lone wolf' dan rawak di pelbagai tempat berkepentingan di negara masing-masing. Beliau turut memuji tindakan pengeboman gereja di Sri Lanka yang mengorbankan 250 nyawa pada 21 April 2019 sebagai satu contoh tindakan yang boleh dilakukan.

Seruan lebih jelas dan tegas oleh Abū Muș'ab al-Sūrī dalam tulisannya The Global Islamic Resistance Call beberapa tahun sebelum itu yang mengajak mereka yang menyokong perjuangan tersebut untuk melakukan serangan bersendirian khususnya di Barat tanpa perlu melalui organisasi pusat. ${ }^{59}$ Justeru, propaganda seperti yang dilakukan al-Baghdādī dan tulisan taktikal oleh alSūrī ini menunjukkan kemungkinan ancaman keganasan boleh berlaku di mana sahaja dan membabitkan sesiapa sahaja. Tambahan pula, tewasnya ISIS turut menyaksikan tahanantahanan yang terlibat untuk mula pulang ke negara asal masingmasing. PDRM mencatatkan bahawa seramai 40 warga Malaysia yang ditahan di Syria dan dipercayai terlibat dengan kegiatan militan ISIS merayu untuk pulang ke tanah air. ${ }^{60}$

\section{Penutup}

Secara umumnya matlamat utama gerakan radikal dan teroris yang menggunakan agama ialah untuk mendapatkan sokongan massa umat Islam. Namun, fahaman melampau ini sebaliknya ditolak masyarakat kerana ia telah memberikan tafsiran salah tentang jihad dan memberikan gambaran negatif terhadap Islam atau perlakuan dan sikap yang mereka tunjukkan. Walaubagaimanapun tidak dinafikan pasti ada yang cenderung untuk terlibat khususnya apabila mereka memenuhi kelima-lima faktor seperti yang dinyatakan. Justeru, usaha pengawalan fahaman terorisme seharusnya ditumpu, dicegah dan dikawal berpandukan faktor tersebut. Walaupun terdapat beberapa faktor di luar kawalan seperti konflik yang berlaku namun, aspek lain seperti pencegahan penyebaran ideologi mampu ditangani melalui jalan pendidikan.

59 Abū Muș'ab al-Sūrī, "The Global Islamic Resistance Call," laman sesawang Internet Archive, dicapai 30 Disember 2019, https://archive.org/stream /TheGlobalIslamicResistanceCall/The_Global_Islamic_Resistance_Call__Chapter_8_sections_5_to_7_LIST_OF_TARGETS_djvu.txt

60 Saifullah Ahmad, "40 Tahanan Malaysia di Syria Mahu Pulang," laman sesawang Sinar Harian, https://www.sinarharian.com.my/article/51859 /BERITA/40-tahanan-Malaysia-di-Syria-mahu-pulang. 
Sehubungan itu, selain penguatkuasaan beberapa akta sedia ada sebagai langkah pencegahan, aspek pendidikan berteraskan pegangan tradisi ulama Ahli Sunnah wal Jamaah perlu terus diperkasakan. Detradisionalisasi pengajian agama atas kehendak pembaharuan dan pemodenan seperti yang diperjuangkan oleh beberapa tokoh pembaharuan pada abad ke-19 dan 20 perlu dinilai semula. Ini kerana pembaharuan yang diingini itu sebaliknya melahirkan kumpulan-kumpulan radikal yang hanya berpegang kepada versi agama yang sempit dan tegar. Pendekatan atau manhaj akidah ulama Nusantara yang sederhana antara pegangan melampau dan liberal telah menyaksikan perkembangan Islam yang aman tanpa perseteruan melampau dan penyemaian keganasan. Justeru proses retradisionalisasi perlu dibugarkan lagi khususnya melalui jalan pendidikan dengan anak-anak muda diperkenalkan semula dengan karya-karya ilmuan Islam bermanhaj sederhana atau wasatiyyah.

\section{Penghargaan}

Makalah ini merupakan sebahagian hasil kajian Geran Penyelidikan Fundamental (FRGS): FRGS/1/2017/SSI03/UM/02/2 (FP022-2017A) yang ditaja oleh Kementerian Penggajian Tinggi Malaysia. Penulis merakamkan penghargaan kepada Kementerian Pendidikan Malaysia dan Universiti Malaya kerana mendanai dan meluluskan kajian ini.

\section{Rujukan}

"Azzam, Abdullah. "Defense of the Muslim Lands: The First Obligation After Iman," laman sesawang Internet Archieve, dicapai 5 Disember 2019, https://archive.org/details/Defense_of the_Muslim_Lands.

"10 Fakta Anda Perlu Tahu Tentang SOSMA." Laman sesawang Astro Awani, dicapai 10 Disember 2019, http://www.astroawani .com/berita-malaysia/10-fakta-anda-perlu-tahu-tentang-sosma76148.

"Bom Movida: Dua lelaki Dipenjara 25 Tahun." Laman sesawang Astro Awani, dicapai 10 Disember 2019, http://www.astroawani .com/berita-malaysia/bom-movida-dua-lelaki-dipenjara-25tahun-137227. 
"Declaration of the World Islamic Front for Jihad Against the Jews and the Crusaders." Laman sesawang World Islamic Front Statement, 23 Februari 1998, dicapai 25 Disember 2019, https://fas.org/irp/world/para/docs/980223-fatwa.htm

"Islamic State Recruiter Targeted Local Schoolboy Police Say." Laman sesawang Malaymail, dicapai 5 Disember 2019, https://www.malaymail.com/news/malaysia/2014/10/14/islamic -state-recruiter-targeted-local-schoolboy-police-say/763167

"K'jaan Sedia Kertas Putih Kegiatan Keganasan Libatkan Rakyat M'sia." Laman sesawang Astro Awani, dicapai 6 Disember 2019, http://www.astroawani.com/berita-malaysia/kjaansediakertas-putih-kegiatan-keganasan-libatkan-rakyat-msia-47177

"RUU Pencegahan Keganasan 2015 (POTA) dibentang di Dewan Rakyat." Laman sesawang Astro Awani, dicapai 10 Disember 2019, http://www.astroawani.com/berita-malaysia/ruupencegahan-keganasan-2015-pota-dibentang-di-dewan-rakyat56747.

"Statistik Tangkapan Elemen Daesh di Bawah POTA." Laman sesawang Portal Data Terbuka Malaysia, dicapai 19 Disember 2019, http://www.data.gov.my/data/ms_MY/dataset/statistiktangkapan-elemen-daesh-dibawah-pota-20142017/resource/74a08629-654e-4927-b8a4-6c734ea1019f.

"Who Was Abu Bakr al-Baghdadi?." Laman sesawang BBC News, dicapai 9 Novermber 2019, https://www.bbc.com/news /world-middle-east-50200392

Abdullah 'Azzam. "Join the Caravan," dicapai 5 Disember 2019, https://ebooks. worldofislam.info/ebooks/Jihad/Join\%20the\%20 Caravan.pdf

Abū Bakr Nājīi, The Management of Savagery, terj. William McCants, dicapai 10 Nov 2019, http://media.leeds.ac.uk/papers /vp0167b8.html.

Ahmad El-Muhammady (panel pakar deradikalisasi tahanan teroris) dalam temu bual bersama penulis, 13 Ogos 2018.

Al-Azharī, Usāmah Sayyīd. Al-Haqq al-Mubìn fì al-Rad 'alā man Tala 'aba bi al-Dīn: al-Tayyārāt al-Mutațarrifah min al-Ikhwān ilā al-Dā'ish fì Mīzān al- 'Ilm. Abu Dhabi: Dār al-Faqīh, 2016.

Al-Sūrī, Abū Muṣ'ab. "The Global Islamic Resistance Call." Laman sesawang Internet Archive, dicapai 30 Disember 2019, https://archive.org/stream/TheGlobalIslamicResistanceCall/The 
_Global_Islamic_Resistance_Call_-_Chapter_8_sections_5_to _7_LIST_OF_TARGETS_djvu.txt

Aminah (isteri kepada tahanan pesalah di bawah SOSMA), dalam temu bual bersama penulis, 19 Ogos 2018.

Amran Muhammad (panel pakar deradikalisasi tahanan teroris) dalam temu bual bersama penulis, 7 Ogos 2018.

Che Mohd Aziz Yaacob et. al. Tahap Kefahaman dan Potensi Penerimaan Pelajar IPTA Terhadap Gerakan ISIS. Kuala Lumpur: Unit Penerbitan IYRES, 2016.

Department of Homeland Security, Centre of Excellent University of Maryland. "Study of Terrorism and Response to Terrorism." Department of Homeland Security Emeritus Center of Excellence, dicapai 10 Disember 2019, http://www.start.umd .edu/research-projects/global-terrorism-database-gtd.

Hedaya, Robert J. The Teenager's Brain: Do You Understand Your Teenager's Thoughts?, hedayahedaya, dicapai 9 Januari 2020, https://www.psychologytoday.com/us/blog/health-matters /201006/the-teenagers-brain.

Institut Penyelidikan Pembangunan Belia Malaysia, Kementerian Belia dan Sukan Malaysia, Ringkasan Eksekutif Profil Belia dalam Kegiatan Ekstremisme. Putrajaya: KBS, 2017.

Institut Penyelidikan Pembangunan Belia Malaysia. Kajian Pembangunan Kesejahteraan-Pendidikan Agama dan Penglibatan dalam Gerakan Islam Radikal di Kalangan Belia Malaysia. T.tp.: t.p., 2015.

John L. Esposito (Profesor Agama, Hubungan Antarabangsa dan Pengajian Islam, Georgetown University, Washington D.C;

John L. Esposito (Profesor Agama, Hubungan Antarabangsa dan Pengajian Islam, Georgetown University, Washington D.C.), dalam temu bual bersama penulis, 19 April 2018.

Kamarulnizam Abdullah. "Kumpulan Mujahidin Malaysia (KMM) and Jemaah Islamiyah (JI): The links," Journal of Policing: Intelligence and Counter Terrorism (2009), 29-46.

Ladin, Usamah bin. Declaration of Jihad Against the Americans Occupying the Land of the Two Holy Mosques. London: alQuds al-'Arabī, 1996.

Laws of Malaysia, Act 747, Security Offences (Special Measures) Act 2012, 9-10. 
Mills, Albert J. ed. Descriptive Case Study, Encyclopedia of Case Study Research. California: Sage Publications, 2010.

Moghadam, Assaf. "Motives for Martyrdom: Al-Qaida, Salafi Jihad, and the Spread of Suicide Attacks." International Security 33, no. 3 (Winter, 2008/2009), 63.

Nursalihah Ahmad Raston et. al. Faktor-faktor yang Mempengaruhi Kecenderungan Keterlibatan Belia di Malaysia dalam Gerakan Islam Radikal. T.tp.: t.p., t.t.

Nursalihah Ahmad Raston et. al. Persepsi Belia di Malaysia Terhadap Jihad dan Gerakan Islam Radikal. Kuala Lumpur: Unit Penerbitan IYRES, 2016.

Patrick Cockburn, The Rise of Islamic State: ISIS and the New Sunni Revolution. London: Verso, 2015.

Pegawai $1 \& 2$ (Unit E8, Bahagian Counter Terrorism, Cawangan Khas, PDRM) dalam temu bual bersama penulis, 12 Julai 2018

Perlembagaan Persekutuan. Kuala Lumpur: International Law Book Service, 2018.

Rapoport, David C. "The Four Waves of Modern Terrorism." The UCLA International Institute, dicapai 11 Disember 2019, http://international.ucla.edu/media/files/Rapoport-Four-Wavesof-Modern-Terrorism.pdf, 47.

Saifullah Ahmad. "40 Tahanan Malaysia di Syria Mahu Pulang." Laman sesawang Sinar Harian, https://www.sinarharian.com .my/article/51859/BERITA/40-tahanan-Malaysia-di-Syriamahu-pulang. Akses?

United Nation, Resolution 2178 (2014); “Threats to International Peace and Security Caused by Terrorist Acts, laman sesawang UNSCR Search Engine for the United Nations, dicapai 19 Disember 2019, http://unscr.com/en/resolutions/2178

United Nations Office of Counter-Terrorism,. "Enhancing the Understanding of the Foreign Terrorist Fighters Phenomenon in Syria." dicapai 19 Disember 2019, https://utveier.no/app /uploads/sites/2/fn-rapport-om-returnerte-fremmedkrigere.pdf

Zam Yusa dan Hadi Azmi. "Balu Pejuang Negara Islam Terbunuh di Syria Pulang ke Malaysia." Laman sesawang Berita Benar, dicapai 10 Disember 2019, https://www.benarnews.org/malay /berita/my-wanita-syria-181025-10252018185716.html. 
Naim dan Syafriz, Faktor Penglibatan Belia dengan Terorisme 